\title{
Kobiety i polityka \\ w świetle opinii prasowych wybranych tygodników („Polityka”, „Newsweek Polska”, „Wprost”)
}

\begin{abstract}
Streszczenie
Artykuł ukazuje obraz kobiet uczestniczacych w polityce oraz ich wizerunki, przedstawione $\mathrm{w}$ oparciu o analizę artykułów prasowych trzech najbardziej opiniotwórczych tygodników, tj. „Polityki”, „Wprost” oraz „Newsweek Polska” (lata 2004-2015). W wyniku analizy prasowej ustalono, że pisma prezentowały kobiety odnoszące sukces na polskiej, jak i światowej scenie politycznej. Kobietami, o których pisano najwięcej były między innymi: Joanna Kluzik-Rostkowska, Hanna GronkiewiczWaltz, Angela Merkel, Hillary Clinton i Sarah Palin. W odniesieniu do analizowanych przekazów prasowych można wywieść, iż wzrastała liczba kobiet, uczestniczacych w życiu politycznym wraz z upływem lat, ale także zauważalna była zmiana jakościowa, przejawiająca się w osiaganiu wyższych stanowisk politycznych przez kobiety.
\end{abstract}

Słowa kluczowe: kobieta • polityka, kobiety w polityce • wizerunek kobiet • „Polityka”, „Wprost”, „Newsweek Polska”

\section{WOMEN AND POLITICS IN PRESS REVIEWS OF SELECTED WEEKLIES ("POLITYKA", "NEWSWEEK POLSKA" AND "WPROST")}

\section{Abstract}

The article shows the role of women in politics and their images based on the analysis of newspaper articles from three the most influ- 
ential weeklies such as "Polityka", "Wprost" and "Newsweek Polska". The research covers press materials appearing from 2004 to 2015, mainly in the pre-election period and refers to the women who succeeded in entering political life such as Joanna Kluzik-Rostowska, Hanna Gronkiewicz-Waltz, Angela Merkel, Hillary Clinton and Sarah Palin. On the basis of the analyzed press material it can be concluded that the political involvement and participation of women has been increasing in recent years. There has also been a significant amount of change regarding women achieving senior leadership positions.

Keywords: woman • policy • women in politics • the image of women •Polityka", "Wprost", "Newsweek Polska"

\section{Uwagi wstępne}

Polityka rozumiana jako dążenie do udziału we władzy oraz wywieraniu wpływu na władzę, czy też potocznie definiowana jako sztuka rządzenia państwem, w przeszłości była sfera aktywności zarezerwowaną właściwie wyłącznie dla mężczyzn. Na scenie politycznej obowiazywał system oparty na męskich wzorcach, w którym brakowało miejsca kobietom, podporzadkowujac je sferze domowej, która nie stanowiła źródła prestiżu i uznania. Podział ról społecznych na typowo kobiece oraz męskie wynika $z$ wielu czynników. W analizie sfery polityki wskazuje się przede wszystkim na wszechobecne stereotypy oraz stygmaty zwiazane $z$ płcia, także na uwarunkowania kulturowe, religijne czy polityczne, wpływające na obecność kobiet w polityce. Dodatkowo do ograniczeń, które wpływaja na niska aktywność kobiet na scenie politycznej, należą cechy osobowościowe kobiet czy też brak umiejętności oraz zainteresowania polityka $z$ ich strony. W celu poprawy sytuacji kobiet $\mathrm{w}$ życiu publicznym uruchamiane sa środki prawne na rzecz zwiększenia ich uczestnictwa w sferze polityki. Do uwarunkowań prawnych należy zaliczyć system kwotowy, parytet oraz system suwakowy. Ponadto zadaniem państwa jest podejmowanie działań służących wyrównywaniu szans obu płci w postaci ustawodawstwa. Tak więc Konstytucja, jako akt najwyższej rangi, ale także ustawy oraz normy prawa międzyna- 
rodowego tworza swoista ochrone praw publicznych przyznanych kobietom.

Środki masowego przekazu, w tym prasa, w dużej mierze skupiają się na prezentowaniu tematów związanych $z$ polityka. $\mathrm{W}$ opracowaniu zostały przedstawione role kobiet $\mathrm{w}$ polityce oraz ich wizerunki $\mathrm{w}$ oparciu o artykuły prasowe trzech najbardziej opiniotwórczych tygodników polskich, to jest „Polityki”, „Wprost” oraz „Newsweek Polska”.

Do niniejszego artykułu wykorzystano treści prasowe prezentowane w tygodnikach od 2004 r. do kwietnia 2015 r., które publikowane były w okresie około 3 miesięcy przed wszystkimi wyborami odbywającymi się w Polsce i 2 tygodnie po nich. Analizie poddano więc tzw. okres wyborczy. Uzupełniająco posłużono się także wydaniami czasopism publikowanych w okresie międzywyborczym oraz tekstami poświęconymi innym ważnym wydarzeniom (jak na przykład śmierć Margaret Thatcher). Przeanalizowano łącznie 720 numerów (po około 240 numerów każdego z pism), co dało 112 artykułów (33 w „Polityce”, 53 we „Wprost”, 26 "Newsweek Polska”), wykorzystując informacje zawarte w formie komunikatów, wywiadów, felietonów oraz reportaży. Spośród prezentowanych tygodników najwięcej tekstów poświęconych problematyce udziału kobiet w polityce opublikował „Wprost”, zaś najmniej „Newsweek Polska”. Na przestrzeni badanych 10 lat widoczne były zmiany w liczbie ukazujących się artykułów poświęconych tematyce uczestnictwa kobiet w polityce. O ile problematyka kobieca $\mathrm{w}$ niewielkim stopniu interesowały się media $\mathrm{w}$ początkowych latach wejścia Polski do Unii Europejskiej (2014 r.), o tyle $z$ każdym kolejnym rokiem tej tematyki było coraz więcej.

Do napisania opracowania została wykorzystana metoda analizy zawartości prasy (analiza treści artykułów poświęconych kobietom polityki), a także zastosowano metodę ilościowa (przeanalizowano treści, które dotyczyły problematyki udziału kobiet w życiu publicznym) oraz metodę jakościową (wykorzystano i ocenio- 
no materiał pod względem przydatności tematu aktywności kobiet i ich wizerunku w polityce) ${ }^{1}$.

Ze względu na analizę artykułów prasowych, ukazujących się w przestrzeni badanych 10 lat, w opracowaniu ujęto tylko w opinii autorki najważniejsze teksty poświęcone kobietom aktywnie działającym w życiu publicznym. W konsekwencji w artykule zostały przedstawione wybrane wizerunki kobiet polskiej oraz zagranicznej sceny politycznej.

\section{Wizerunek kobiet na lamach „Polityki”}

Tygodnik „Polityka” zaliczany jest do tzw. prasy opinii o społeczno-politycznym charakterze, którego początki sięgaja 1957 r. ${ }^{2}$ Pismo reprezentuje profil liberalno-lewicowy i porusza tematy, problemy i wydarzenia polityczne, gospodarcze, społeczne, naukowe i kulturowe $z$ Polski, Europy i świata. Uznawane jest za fenomen $\mathrm{w}$ kategorii czasopism opiniotwórczych, m.in. dzięki pracującym tam dziennikarzom. Zatrudnieni w niej publicyści i felietoniści zaliczani sa do najlepszych w kraju, posługuja się głębszymi analizami i przemyśleniami. W 2014 r. „Polityka” była najlepiej sprzedajacym się tygodnikiem opinii w Polsce ${ }^{3}$.

Pismo w badanym przedziale czasowym wielokrotnie prezentowało treści dotyczące barier w karierze politycznej kobiet. Przykładem były artykuły odnoszące się do stereotypów i tradycyjnego podziału ról w społeczeństwie, ale także treści wskazujące na ograniczenia kobiet, wynikajace $z$ takich zjawisk, jak szklane schody, szklany sufit czy też lepka podłoga4. „Polityka” poświęciła

\footnotetext{
${ }^{1}$ Szerzej na temat uzasadnienia metody zob. M. Dajnowicz, Wizerunek kobiet polityki. Polska na tle państw zachodnich (na podstawie analizy treści wybranych tygodników), „Studia Podlaskie” 2014, t. 22, s. 130.

2 I. Hofman, Wzór redaktora - model redakcji: „Tygodnik Powszechny”, „Polityka”, „Twórczość” [w:] Prasa dawna i współczesna, cz. 3, red. B. Kosmanowa, Poznań 2002, s. 77.

3 [Dostęp: 28.09.2015]. Dostępny w World Wide Web: <http://bit.ly/2gx0w61>.

4 Zob. przykładowe artykuły: E. Wilk, Babskie gadanie, „Polityka” 2014, nr 13,

s. 28; J. Podgórska, Po niej już nigdy nie było tak samo, „Polityka” 2004, nr 6, s. 8;

E. Winnicka, Jak wychować dziecko w weekend, „Polityka” 2004, nr 6, s. 3.
} 
również kilka artykułów na ukazanie drogi, jaką kobiety musiały pokonać, by obecnie móc w pełni korzystać ze swoich praw 5 .

Tygodnik „Polityka” przy okazji odbywajacych się wyborów prezydenckich, parlamentarnych, samorzadowych oraz do Parlamentu Europejskiego niejednokrotnie ukazywał wizerunki kobiet polityki. W analizowanym przedziale czasowym, tj. od 2004 do 2015 roku, pismo prezentowało głównie obraz Polek odnoszących sukces na scenie politycznej.

Periodyk szczególną uwagę poświęcił Danucie Hübner ze względu na sukces, jaki osiągnęła w kontekście członkostwa Polski w Unii Europejskiej. Już na samym poczattku jej europejskiej kariery jako komisarz budziła ogromne zainteresowanie wśród pozostałych przedstawicieli państw członkowskich. Podkreślano, że była doskonale przygotowana do pełnienia swojej funkcji -

(...) miała znaczna wiedzę na temat dziedziny, w której będzie $\mathrm{w}$ przyszłości pracować. Była też w stanie udzielić zadawalających i otwartych odpowiedzi na większość pytań z jej dziedziny6.

Jej doskonałe przygotowanie, profesjonalizm, ciężka praca oraz opanowanie wyniosły Hübner na szczyty kariery politycznej. Po objęciu mandatu europosła pisano o niej, że jest siła autorytetu. Przedstawiano ją jako kobietę odważną i niezależną oraz zdolną do głoszenia odmiennych poglądów od frakcji, do której należała, a nawet polskiego rządu ${ }^{7}$. Czytelnicy „Polityki” w jednym $z$ rankingów, organizowanych przez pismo, uznali Hübner za najbardziej wpływową kobietę w Polsce. Docenili jej mądrość, konsekwencję oraz zaangażowanie we wszystkie działania, które podejmowała. Dodatkowo podkreślano jej doskonałe zdolności dyplomatyczne, które przełożyły się na przekonanie społeczeństwa, że kobieta może być lepszym politykiem niż mężczyzna .

5 Zob. przykładowe artykuły: J. Podgórska, Chcemy całego życia!, „Polityka” 2008, nr 48, s. 70-73; M. Ostrowski, J. Winiecki, Niech żyje mała różnica, „Polityka” 2009, nr 10, s. 80-83; E. Bendyk, Zmiana płci, „Polityka” 2010, nr 42, s. 61.

${ }^{6}$ M. Safuta, Twarze komisarzy, „Polityka” 2004, nr 22, s. 44-47.

7 A. Mazurczyk, J. Winiecki, Prymusi i pośle ławki, „Polityka” 2010, nr 24, s. 24.

8 J. Podgórska, Po niej już nigdy..., op. cit., s. 82. 
Innym przykładem kobiety sukcesu polskiej sceny politycznej, budzącej zainteresowanie publicystów „Polityki”, była Joanna Kluzik-Rostkowska. Sylwetka Kluzik-Rostowskiej prezentowana była w kontekście mianowania jej na podsekretarza stanu w Ministerstwie Pracy i Polityki Socjalnej oraz pełnienia przez nia funkcji pełnomocniczki do spraw kobiet i rodziny w rzadzie Jarosława Kaczyńskiego. Pisano o niej, że jest znakomita specjalistka $\mathrm{w}$ swojej dziedzinie bez politycznego zacietrzewienia, ale $z$ wielka determinacja broni swoich pomysłó $w^{9}$. Kluzik-Rostowska wiele razy podkreślała potrzebę istnienia faktycznej równości między kobieta, a mężczyzną, ale odmiennie od wielu środowisk politycznych mówiła, że aby to zmienić należy przede wszystkim umacniać pozycje kobiet w społeczeństwie, rodzinie i w związku, a nie prowadzić walkę i skupiać się wyłącznie na rozwiazaniach formalnych, np. ustawach równościowych ${ }^{10}$. Na łamach „Polityki” w 2010 r. pojawił się tekst dotyczacy nowopowstajacej partii politycznej - Polska Jest Najważniejsza (PJN), której inicjatorka i przewodnicząca zarazem była Kluzik-Rostowska. Również i na tej płaszczyźnie działalności odniosła sukces. Wskazywano, że dzięki merytorycznemu programowi, tożsamości i wizji ugrupowania oraz doświadczeniu przewodniczącej w prowadzeniu aktywnej polityki społecznej i prorodzinnej PJN, chociaż formalnie jeszcze nie istniała, to w sondażach wyborczych triumfowała, przekraczając pięcioprocentowy próg wyborczy, co bez watpienia było wielkim osiagnięciem nie tylko partii, ale również samej KluzikRostowskiej ${ }^{11}$.

Kobieta, która również interesowały się media papierowe była Hanna Gronkiewicz-Waltz. „Polityka” w jednym ze swoich artykułów poświęciła znaczną cześć tekstu życiorysowi obecnej Prezydent Warszawy, gdyż jak stwierdzono, po objęciu fotela prezydenckiego stała się jedną $z$ najbardziej wpływowych osób na scenie politycznej12. W tekście wymieniono stanowiska, jakie obej-

9 J. Paradowska, A. Dabrowska, Liderzy, debiutanci, maruderzy, „Polityka” 2008, nr 39, s. 27; A. Lach, Kluzica, „Newsweek Polska” 2010, nr 48, s. 26-28.

10 J. Cieśla, E. Wilk, Kobieta petnomocna, „Polityka” 2005, nr 47, s. 26.

11 J. Żakowski, Kluziki na kredyt, „Polityka” 2010, nr 49, s. 16.

12 J. Cieśla, A. Rybak, Przypadki pani Hani, „Polityka” 2006, nr 49, s. 28. 
mowała Gronkiewicz-Waltz od wiceprezesa ds. administracyjnych i kadrowych w Europejskim Banku Odbudowy i Rozwoju (EBOR), następnie zasiadała w Radzie Forum Ekonomicznego w Krynicy oraz pełniła funkcję pełnomocnika zarządu regionalnego ds. Warszawy, po wpływowa działaczkę Klubu 22. Podkreślano przy tym jej rzeczowe przygotowanie, niezależność, stalowy rozsadek oraz zmyst organizacyjny 13 .

Inna kobieta polskiej sceny politycznej dostrzeżona przez media była Ewa Kopacz, była Prezes Rady Ministrów. W jednym $z$ nagłówków „Polityki” pojawiło się stwierdzenie, że Ewa Kopacz uchodzi za najtwardsza osobe $w$ rzadzie, wtedy jeszcze Donalda Tuska. Na dowód tego określenia autorka tekstu przedstawiła drogę, jaka pokonała premier, by w ten sposób o niej pisano. Od bycia lekarzem doszła do lokalnej polityki, dalej utworzyła Konfederacje Kobiet, zaczęła działać w klubie Unii Wolności, a następnie jej pozycja wzrosła do rangi ministra-pracoholiczki. Doświadczenie, jakie dotychczas zdobyła podczas działalności politycznej, bez watpienia stworzyły $z$ niej obraz niezwykle silnej kobiety oraz zdeterminowanej i niezależnej osoby ${ }^{14}$.

„Polityka” w swoich numerach kreowała również kobiety działające w sferze publicznej początków XXI wieku. Przykładem jest artykuł z 2004 r. poświęcony Róży Thun, który pojawił się w kontekście startowania przez nia do Parlamentu Europejskiego. Tekst poświęcony był głównie bogatemu życiorysowi kobiety, zwracał uwage na jej życie rodzinne, przodków oraz arystokratyczne pochodzenie. Eksponowano również priorytety i wartości, które wyznawała. Na pierwszym miejscu był Bóg, następnie rodzina, a dopiero później działalność społeczna i publiczna. Wyznawana przez nia hierarchia wartości budowała staroświecki i konserwatywny wizerunek Thun, który jednak nie przeszkodził jej w karierze politycznej, gdyż, jak pisano - jej katolickość jest prywatna $i$ schowana. Kandydatka na posła do Parlamentu Europejskiego eksponowana była głównie przez aktywność w Fun-

13 Ibidem, s. 31, W tygodniku „Wprost” również odnaleźć można informacje dotyczące życiorysu H. Gronkiewicz-Waltz w artykule - A. Pawlickiej, Żelazna Hanna, „Wprost” 2010, nr 40, s. 23-24.

14 M. Bunda, Kobieta pracujaca, „Polityka” 2010, nr 28, s. 28-29. 
dacji Schumana. Jako prezes apolitycznej organizacji pozarzadowej postrzegana była jako osoba łatwo nawiazujaca kontakt $z$ otoczeniem, ujmujaca bezpośredniościa, potrafiaca narobić szumu oraz okazała się być niezwykle medialna postacia. Wszystkie $z$ wymienionych cech, ale także wykształcenie, doskonała znajomość języków obcych oraz wspomniane wcześniej pochodzenie uczynily Thun politykiem godnym kandydowania do struktur unijnych ${ }^{15}$.

Również w kontekście eurowyborów, ale już 10 lat później (w 2014 roku), „Polityka” eksponowała postać Barbary Nowackiej jako córkę Izabeli Jarugi-Nowackiej, wicepremier w rządzie Marka Belki, tragicznie zmarłej w katastrofie smoleńskiej. Publicystka „Polityki” pisze - Swoich przekonań broni umiejętnie i z duża klasa, czym przypomina swoja matke. Doświadczenia, jakie zdobyła u boku matki, wyniosły ja na szczyt kariery. Stała się odkryciem eurokampanii $i$ nadzieja lewicy oraz okrzyknięto ja politycznym objawieniem. O Nowackiej pisano i mówiono wyłącznie w pozytywny sposób:

Ma atuty, które sa niesłychanie ważne: wiedzę, opanowanie i zdrowy rozsądek. (...) Ma charyzmę i energię. Ludzie wierza w to, co mówi, bo widać, że to idzie z serca. To ważny, ale i rzadki przymiot polityka. (...) Jest dobrze wykształcona i śliczna.

Tego rodzaju stwierdzeń w artykule było znacznie więcej, co wpływało wyłącznie na korzyść kandydatki do Parlamentu Europejskiego ${ }^{16}$.

Tygodnik „Polityka” eksponował nie tylko obraz polskich kobiet polityki, ale także można odnaleźć w nim artykuły poświęcone kobietom sprawującym władzę w różnych państwach Europy i świata. Jedna z nich była kanclerz Niemiec Angela Merkel. Tekst opublikowany w 2004 r. dotyczył trwających w Niemczach kłopotów zwiąanych $z$ funkcjonowaniem patii politycznych, do jednej z nich należała Merkel. Niemal cały artykuł opisuje najpierw życie

15 A. Rybak, Róża Europy, „Polityka” 2004, nr 8, s. 32-34.

16 M. Dziedzic, Przyczajona lewica, „Polityka” 2014, nr 25, s. 22-24. 
prywatne, a później zawodowe i publiczne kanclerz. Gdy Merkel dochodziła do władzy, nazywano ja dziewczynka Kohla i zastanawiano się czy może rządzić męskim narodem? Przecież ona nie ma pojęcia ani o gospodarce, ani o polityce zagranicznej! Jest ze Wschodu, a poza tym to kobieta! Okazało się, że Merkel - jak pisze publicysta - jest najbardziej wpływowa kobieta w Niemczech ${ }^{17}$.

Innym przykładem kobiety odnoszącej sukces w świecie wielkiej polityki była Hilary Clinton. Wizerunek kreowany przez media związany był $z$ jej nominacja na stanowisko sekretarza stanu USA, a później $z$ kandydatura do Białego Domu. We wszystkich tekstach poddawanych analizie Pierwsza Dama uchodziła za osobę o wyjatkowo silnej osobowości, inteligentna, ambitna oraz petna zdolności i talentu ${ }^{18}$. Jako niezaprzeczalny atut Clinton podawano intelektualna dyscypline, profesjonalizm $i$ site charakteru, wyczuwalna u prawdziwych przywódców ${ }^{19}$. Wszystkie te cechy wyniosły ja najpierw do Departamentu Stanu, gdzie obejmowała niezwykle prestiżowy urząd, czwarty po prezydencie. Jako szefowa amerykańskiej dyplomacji uchodziła za jastrzębia, zwolenniczkę muskularnej polityki zagranicznej20. Później, gdy rozpoczęła zmagania o fotel prezydencki pisano, że $w$ USA uchodzi za jednego $z$ nielicznych polityków wagi ciężkiej. Potrafi godzinami mówić bez kartki-z sensem $i$ bez zajaknięcia ${ }^{21}$.

Wszystkie obrazy kobiet prezentowane przez „Politykę” skłaniaja do stwierdzenia, że zarówno Polki jak i kobiety światowej sceny politycznej, bez względu na to, jak sa postrzegane i oceniane, odniosły sukces w szeroko rozumianej sferze życia politycznego.

\footnotetext{
17 A. Krzemiński, Żelazna dziewczynka, „Polityka” 2004, nr 45, s. 50-52.

18 A. Lubowski, Hilary do pary, „Polityka” 2014, nr 22, s. 47.

19 Ibidem, Dynastia, „Polityka” 2015, nr 16, s. 56.

20 Ibidem, Jastrzab w szpilkach, „Polityka” 2008, nr 49, s. 85.

21 Ibidem, Dynastia, „Polityka” 2015, nr 16, s. 56-58.
} 


\section{Kobiety w polityce w opiniach tygodnika „Wprost”}

Tygodnik „Wprost” jako czasopismo opiniotwórcze po raz pierwszy ukazał sie 5 grudnia 1982 r. w Poznaniu. Poczatkowo było to pismo regionalne, sprzedawane wyłącznie w Wielkopolsce. Od 1989 r. „Wprost” stał się tygodnikiem ogólnopolskim, a w 2000 r. Warszawa została jego siedzibą 22 . Profil periodyku i preferowane wartości zmieniały się wraz $z$ redaktorami naczelnymi i pracującymi dziennikarzami. Naczelny Marek Król podczas pełnienia funkcji zmieniał linie programowe tygodnika od lewicowych po skrajnie prawicowe. W 2010 r. „Wprost” uznawano za pismo liberalno-konerwatywne, Tomasz Lis przeobraził profil na umiarkowanie centrowy ${ }^{23}$.

Tygodnik „Wprost” temat uczestnictwa politycznego kobiet eksponował m.in. poprzez artykuły odnoszace się do praw kobiet i dróg, jakie musiały one pokonać, by móc w pełni korzystać $z$ przyznanych im praw. Na jednej $z$ okładek tygodnika widniało hasło Powrót kobiety. Główny temat numeru obrazował etapy, które pokonywały kobiety, by obecnie móc decydować o własnym życiu. Zaprezentowano i wyjaśniono pojęcie feminizmu, postfeminizmu, czy też neofeminizmu, które społeczeństwo niejednokrotnie błędnie rozumiało 24 .

W tygodniku „Wprost” odnaleźć można liczne artykuły poświęcone kobietom, sprawujacym realną władzę oraz zajmujących wysokie stanowiska w strukturach państwowych. Polskimi kobietami czynnie uczestniczącymi w życiu publicznym i politycznym kraju, prezentowanymi przez gazetę, były Gronkiewicz-Waltz oraz Kopacz. Podobnie jak w „Polityce”, na łamach „Wprost” skupiono się w dużej mierze na sukcesach obu pań. Obie kilkakrotnie znalazły się $\mathrm{w}$ rankingach najbardziej wpływowych Polek, $\mathrm{z}$ tą różni-

22 [Dostęp: 2.09.2015]. Dostępny w World Wide Web: <http://bit.ly/2fQ27Db>. 23 B. Dobek-Ostrowska, Polski system medialny na rozdrożu: media $w$ polityce, polityka $w$ mediach, Wrocław 2011, s. 146-147.

24 A. Koziński, Powrót kobiety, „Wprost” 2006, nr 45, s. 70. 
ca, że Gronkiewicz-Waltz plasowała się w czołówce, zaś Kopacz na nieco dalszej pozycji 25 .

W periodyku nie zabrakło również tytułów poświęconych kolejnym paniom prezydentowym. Pierwsze damy bardzo często pojawiały się na łamach tygodnika "Wprost”, głównie $z$ racji faktu bycia żona głowy państwa.

„Wprost” o Jolancie Kwaśniewskiej pisało nie w kontekście jej męża oraz głównie jako założycielce fundacji Porozumienie bez Barier. $Z$ racji powołania do życia i funkcjonowania fundacji, pomagającej ludziom niepełnosprawnym i pokrzywdzonym, pierwsza dama była darzona ogromnym szacunkiem przez Polaków. Miliony ludzi ceniło ją za wrażliwość i chęć niesienia pomocy w formie działalności charytatywnej. Nawet podejrzenia zwiąane $z$ nieuczciwymi finansami jej fundacji nie wpłynęły na sposób postrzegania pani prezydentowej26.

Kolejna pierwsza damą, której tygodnik poświęcił wiele artykułów, była Maria Kaczyńska. „Wprost” wyeksponował wyłącznie pozytywny obraz prezydentowej. Podkreślano przede wszystkim jej wrażliwość i autentyczność. W jednym $z$ wywiadów powiedziała: Moge być tylko Maria Kaczyńska. Jestem jaka jestem i nigdy tego nie zmienię 27 . Prezentowany wizerunek otwartej i życzliwej kobiety przeplatał się ze szczerościa i prawdomównością. Jak sama powiedziała - Nie jestem politykiem, moge mieć własne zda$n i e^{28}$. Nierzadko jej naturalność, przejawiajaca się w wyrażaniu własnych poglądów, często odbiegajacych od haseł prawicy, była krytykowana. Mimo to swoja osoba i postawa ocieplała wizerunek męża, głowy państwa29. Dodatkowo na pozytywny obraz Kaczyńskiej miał wpływ bez wątpienia jej nienaganny wygląd zewnętrzny. Była filigranowa, drobna. Miała piekne włosy, zawsze doskonale uczesane, ładne dłonie $i$ stopy. W przygotowanych dla niej

25 A. Blinkiewicz, K. Nowicka, Prawdziwa Partia Kobiet, „Wprost” 2007, nr 39, s. 22; M. Wójcik, M. Buchowski, Władza kobiet, „Wprost” 2009, nr 10, s. 6-9; M. Wójcik, Wpływowe kobiety polityki, „Wprost” 2010, nr 11, s. 20-21.

26 T. Nałęcz, Dorabianie gęby, „Wprost” 2004, nr 39, s. 14.

27 M. Dzierżanowski, Zawsze byłam soba, „Wprost” 2010, nr 16, s. 18.

28 M. Buchowski, Władza kobiet..., op. cit., s. 7.

29 S. Sachno, A. Sijka, Pary władzy, „Wprost” 2008, nr 42, s. 31. 
jasnych ubraniach wygladała ślicznie ${ }^{30}$. Pisano o jej wrodzonym wdzięku, elegancji i klasie. W dodatku była świetnie wykształcona, władała kilkoma językami oraz zajmowała się działalnościa charytatywna i kulturalna, przez co zyskiwała ogromna rzeszę sympatyków.

Na pochlebną opinię dziennikarzy tygodnika „Wprost” zasłużyła także Anna Komorowska, żona prezydenta Bronisława Komorowskiego. Przedstawiano ja jako osobę ciepła $i$ serdeczna, $z$ ogromnym poczuciem humoru. Jednocześnie podkreślano, że jest twarda, pryncypialna kobieta, której często ulega sam prezydent. Pisano nawet, że Komorowska nigdy nie była $w$ cieniu męża. - Działaja na bardzo partnerskich zasadach, a wręcz To ona $w$ dużym stopniu nadaje dynamike tej prezydenturze. Ona tworzy, wymyśla, jest aktywna ${ }^{31}$. Podkreślano także jej sceptyczne podejście do publicznych wystapień, udzielania wywiadów czy też zabierania głosu w kwestiach politycznych ${ }^{32}$.

W 2010 r., po katastrofie smoleńskiej, tygodnik „Wprost” poświęcił sporo miejsca ofiarom tragicznego wypadku. Wśród wielu wspaniałych polityków znalazły się: Katarzyna Doraczyńska, Izabela Tomaszewska, Izabela Jaruga-Nowacka, Grażyna Gęsicka, Aleksandra Natalli-Świat, Krystyna Bochenek oraz Jolanta Szymanek-Deresz. Publicyści „Wprost” pisali wyłącznie ciepłe słowa o zmarłych kobietach. Podkreślali ich kompetencje, profesjonalizm, determinacje $i$ to, jak wiele zrobiły dla naszego kraju. Nie zabrakło także stwierdzeń dotyczących urody, elegancji i wdzięku polskich kobiet polityki ${ }^{33}$.

30 A. Bojańczyk, Zyskiwała z wiekiem, „Wprost” 2010, nr 17, s. 10.

31 A. Gielewska, Kariatyda i jej szparagi, „Wprost” 2012, nr 47, s. 29-30.

32 A. Pawlicka, G. Łakomski, Belferka z Belwederu, „Wprost” 2010, nr 43, s. 22 24.

33 K. Ciesiołkiewicz, Dla niej nie istniały problemy, „Wprost” 2010, nr 17, s. 35; K. Kozłowska, Była polska Desiree Rogers, „Wprost” 2010, nr 17, s. 36; M. Dzierżanowski, Obrywała za szczerość, „Wprost” 2010, nr 17, s. 37; Idem, Prymuska, która się uwielbia, „Wprost” 2010, nr 17, s. 38; M. Krzymowski, Żelazna myszka, „Wprost” 2010, nr 17, s. 38; G. Łakomski, Życzliwa bo szczéśliwa, „Wprost” 2010, nr 17, s. 39; M. Krzymowski, Całowali po rękach, „Wprost” 2010, nr 17, s. 39; Tacy byli (dodatek), „Newsweek Polska” 2010, nr 17, s. 8-39. 
W obliczu tragedii, a później w kontekście kampanii wyborczej, pisano także o matce Jarosława i Lecha Kaczyńskich. Podkreślano, że Jadwiga Kaczyńska była ważną kobietą w życiu obu polityków. Byli bardzo do niej przywiązani, zawsze mogli liczyć na wsparcie matki. Jej korzenie i wychowanie w przedwojennej klasycznej inteligenckiej wojskowej rodzinie spowodowały zacietrzewienie do przekazywania wiedzy o polityce historycznej swoim dzieciom. Kaczyńska, chociaż politykiem nie była, angażowała się $\mathrm{w}$ niektóre sprawy państwowe. Interweniowała co prawda nie publicznie, ale w cieniu swoich synów (np. w przypadku obowiązkowych lektur szkolnych) ${ }^{34}$. Jak pisano - Kaczyńska to niezwykła osobowość, która wywarka ogromny wpływ na braci35.

$Z$ tego samego powodu pisano również o Marcie Kaczyńskiej, córce tragicznie zmarłych Marii i Lecha Kaczyńskich. W tekście, w którym stanowiła główna bohaterkę, skupiono się właściwie wyłacznie na jej życiu prywatnym oraz na relacjach $z$ wujkiem. Stała się bowiem twarza kampanii wyborczej stryja, w której miała ocieplać wizerunek kandydata $\mathrm{PiS}^{36}$.

W gronie kobiet prezentowanych przez tygodnik „Wprost” znalazły się również wdowy po Przemysławie Gosiewskim. Pierwsza żona Małgorzata Gosiewska, posłanka oraz druga żona, senator Beata Gosiewska zostały przedstawione w kontekście sporu o listy do Parlamentu Europejskiego, do którego obie kandydowały. O ile pierwsza $z$ nich funkcjonuje w polityce od lat, o tyle druga rozpoczęła swoja działalność dopiero po śmierci męża. Cała rozprawa nad zasadnościa startowania przez panie Gosiewskie w wyborach opierała się nie tyle o brak kompetencji i przygotowania do pełnienia funkcji, o które się ubiegały, a raczej o nazwisko i osiagnięcia Gosiewskiego ${ }^{37}$.

W odmienny, bo krytyczny sposób gazeta kreowała wizerunek Julii Pitery, Anny Kalaty, czy Magdaleny Ogórek. Wskazywano głównie na brak doświadczenia pań w zajmowaniu się często

34 M. Dzierżanowski, Matka IV Rzeczpospolitej, „Wprost” 2010, nr 27, s. 35-37.

35 K. Nowicka, Matriarchat IV RP, „Wprost” 2007, nr 32/33, s. 30-31.

36 M. Krzymowski, Operacja Marta, „Wprost” 2010, nr 25, s.9-12; C. Łazarewicz, V. Ozminkowski, Strażniczka pamięci, „Newsweek Polska” 2012, nr 41, s. 23-24. 37 J. Apelska, Trzy Gosiewskie w jednym PiS, „Wprost” 2014, nr 5, s. 32-34. 
przez nie różnymi sprawami, nie zapominając jednak o podkreślaniu nienagannej prezencji kobiet polityki ${ }^{38}$.

Tygodnik „Wprost” poza eksponowaniem kobiet polskiej sceny politycznej, w dużej mierze skupił się także na kobietach polityki państw szeroko rozumianego zachodu.

Głównym kierunkiem zainteresowania publicystów okazały się Stany Zjednoczone Ameryki, gdyż w wielu artykułach prasowych pojawiły się takie nazwiska, jak: Clinton, Condoleezza Rice, Sarah Palin czy Michelle Obama. Pierwsza z nich, podobnie jak w „Polityce”, występowała w przekazach prasowych, dotyczacych wyborów prezydenckich USA w 2016 r. Niemal wszystkie artykuły poświęcone Clinton ukazywały jej trudna drogę do polityki. Nie zabrakło też stwierdzeń, odnoszących się do jej cech charakteru, które miały wpływ na karierę. I tu podobnie jak w „Polityce” pisano o niej - ambitna, dzielna, bojowa, nieskruszona, nieustepliwa, bezpośrednia, pragmatyczna (...). Prezentowany image zimnej baby ze stali był jednym $z$ największych zmartwień jej samej, ale też całego sztabu HRC. Próby ocieplania wizerunku okazały się priorytetem prowadzonej kampanii, gdyż jak pisano - Amerykanie musza uwierzyć, że jest kimś więcej niż tylko twarda, profesjonal$n a$ (...). A gdy to się uda, wygra wyścig do Białego Domu39.

W odmienny od Clinton sposób eksponowano sylwetkę Rice doradczyni prezydenta do spraw bezpieczeństwa narodowego, a później sekretarz stanu USA. Rodzina, w której się wychowała, doświadczenia życiowe, spowodowane czarnym kolorem skóry oraz pracowitość doprowadziły Rice na sam szczyt kariery. Profesjonalna i elegancka, ale też błyskotliwa, nieustepliwa i znakomita

\footnotetext{
38 K. Wronowska, Bestia i piękna, „Wprost” 2010, nr 39, s. 53-55; M. Krzymowski, Pani minister na tropie, „Wprost” 2010, nr 44, s. 44-45; E. Olczyk, Czasami jestem za grzeczna, „Wprost” 2015, nr 19, s. 18-19.

39 T. Deptuła, Taka zwyczajna Hillary, „Wprost” 2015, nr 17, s. 62; P. Milewski, Świat według Hillary, „Wprost” 2010, nr 29, s. 86-88; M. Jarkowiec, Grzanie Hillary, „Wprost” 2014, nr 8, s. 84-86; Idem, Clintonowie rzadza. Dynastia, „Wprost” 2014, nr 8, s. 84-86; P. Milewski, Szanse Hillary Clinton. Prezydentka, „Newsweek Polska” 2014, nr 12, s. 59-60; P. Milewski, Malinowa Hillary, „Newsweek Polska” 2015, nr 12, s. 58-60; P. Milewski, Plusy ujemne Hillary, „Newsweek Polska” 2015, nr 16, s. 47-49.
} 
$w$ kontaktach $z$ mediami realizowała stawiane przed nia kolejne wyzwania ${ }^{40}$. Media pisały o Rice nie tylko ze względu na jej pozycję $\mathrm{w}$ Ameryce, ale także $z$ powodu zainteresowania $z$ jej strony Europa i Polską. W 2008 r. "Wprost” opublikował artykuł, który był poświęcony podpisaniu umowy przez Radosława Sikorskiego i Rice w sprawie budowy tarczy antyrakietowej w Polsce. W tekście nie zabrakło też pochwał w kierunku szefowej amerykańskiej dyplomacji. Pisano, że swoja prace traktuje jak misję. Poświęciła sie jej całkowicie - nie znalazła czasu na założenie rodziny. Efektem pracowitości i zaangażowania w politykę było przyznanie jej przez magazyn „Forbes” dwukrotnie tytułu najbardziej wpływowej kobiety świata ${ }^{41}$.

W równie przychylny sposób co Rice media oceniły sylwetkę Palin, ówczesnej gubernator Alaski. O Palin pisano w kontekście kandydowania przez nią w 2008 r. na wiceprezydenta Stanów Zjednoczonych. Chociaż wywoływała skrajne reakcje wśród wyborców, nie zabrakło również pozytywnych określeń w stosunku do jej osoby. Wymieniano jej konkretne doświadczenie i wymierne osiagnięcia ${ }^{42}$. Autorka innego tekstu, także poświęconego gubernator, wymieniała właściwie wyłącznie jej cechy pozytywne. Wskazywała na inteligencję, bystrość, niezłomność, energiczność oraz niezwykła urodę Amerykanki. Dodatkowym czynnikiem wpływającym na wzrost poparcia oraz zaufania wśród elektoratu była deklaracja Palin, w której przekonywała, że zajęła się polity$k a$, bo uważała, że nadszedł czas, by kobiety roztrzaskały szklana ściane waszyngtońskich układów. Biografia oraz osobowość gubernator Alaski miała rozstrzygnąc wyniki wyborów prezydenckich Stanów Zjednoczonych ${ }^{43}$.

O sławnych kobietach polityki periodyki pisały nie tylko za życia, ale ze względu na wielkie osobowości, także po ich śmierci. Jedną $z$ nich była księżna Walli - Diana, tragicznie zmarła

40 G. Sadowski, M. Fita-Czuchnowska, Doktryna Condoleezzy, „Wprost” 2006, nr 36, s. 106-108; J. Urbanowicz, Stalowa magnolia Busha, „Wprost” 2004, nr 22, s. 91.

41 S. Sachno, Misjonarka Condoleezza Rice, „Wprost” 2008, nr 35, s. 38.

42 T. Sowell, Typki w Białym Domu, „Wprost” 2008, nr 22, s. 114-115.

43 M. Nagórska, Miss Barakuda, „Wprost” 2008, nr 37, s. 87-88. 
w 1997 r. (w wypadku samochodowym). Diana była uwielbiana przez Brytyjczyków, według nich była ucieleśnieniem snu o kopciuszku i "ludzka pania". Zjednywała sobie ludzi jako anioł miłosierdzia, który pochyla sie nad chorymi na AIDS, afrykańskimi dziećmi $i$ ofiarami wojny (...). Księżna postrzegana jako niewinna męczennica, skrzywdzona przez męża i teściową, zaraz po śmierci stała się nadzwyczaj popularna. W Wielkiej Brytanii ludzie oszaleli na punkcie Księżnej Diany. 10 lat po wypadku pisze się o kulcie zmarłej. Ludzie tworza w domach ołtarzyki, gromadza jej zdjęcia i pamiątki. Organizowane sa nawet wycieczki szlakiem Diany Spencer. A wszystko to dlatego, jak pisze autorka tekstu, że nikt nie jest w stanie zastapić Księżnej Diany ${ }^{44}$.

Nieco inaczej Brytyjczycy, jak i reszta świata, ocenili poczynania premier Wielkiej Brytanii Margaret Thatcher. Po śmierci Żelaznej Damy w przekazach prasowych wyliczano właściwie same niekorzystne decyzje pani premier, które wpłynęły na gospodarkę kraju. Po ogłoszeniu komunikatu o śmierci Thatcher, w przeciwny sposób niż miało to miejsce w przypadku śmierci Księżnej Diany, na ulicach miast ludzie śpiewali, bawili się, wykrzykując hasła dalekie od wyrazów szacunku dla zmarłej45. Negatywnie kreowany wizerunek Thatcher próbował zmienić $\mathrm{w}$ jednym $\mathrm{z}$ artykułów polski tłumacz pracujący w MSZ, towarzyszący Żelaznej Damie podczas wizyty w Polsce. Jak wyznał Krzysztof Litwiński, Thatcher była elegancka, ciepła, ujmujaca, chwilami nawet miła kobieta (...) $z$ ewidentnymi śladami dużej urody $(. . .)^{46}$.

Wszystkie kobiety, o których pisano na łamach „Wprost”, jedne bardziej lubiane i doceniane, drugie mniej, bez watpienia można zaliczyć do grona tych, które zasłużyły na miano kobiet sukcesu.

44 D. Cosić, Zombie Diana, „Wprost” 2007, nr 32/33, s. 92-94.

45 M. Bratkowska, Suka, wiedźma, ikona, „Wprost” 2013, nr 16, s. 60-62; A. Szostkiewicz, Tance i Łzy, „Polityka” 2013, nr 16, s. 50- 52.

46 M. Bratkowska, Była wielka Dama, „Wprost” 2013, nr 16, s. 63; M. Rybarczyk, Największa po Churchillu, „Newsweek Polska” 2013, nr 16, s. 59-61. 


\section{Obraz kobiet w świetle „Newsweek Polska”}

Obok „Polityki” i „Wprost” najbardziej popularnym pismem opiniotwórczym o społeczno-politycznym charakterze jest również „Newsweek Polska”47. Jest zarazem najmłodszym $z$ opisanych tygodników, gdyż pojawił się na polskim rynku prasowym dopiero w $2001 \mathrm{r}$.

Tygodnik „Newsweek Polska”, podobnie jak „Polityka” i „Wprost”, w wydawanych numerach wielokrotnie podnosił kwestię potrzeby zwiększenia udziału kobiet w gremiach władzy. Wśród wielu argumentów przemawiających za słusznością wychodzenia kobiet na szczyty kariery podawano m.in. potrzebe stworzenia nowej jakości polityki - ukobieconej, łagodnej, pełnej zgody i harmonii. Wskazano również na inne priorytety kobiet w stosunku do mężczyzn, np. zwrócenie większej uwagi na ochronę zdrowia, szkolnictwo czy ochronę środowiska ${ }^{48}$.

„Newsweek Polska”, podobnie jak dwa wcześniej prezentowane tygodniki, w publikowanych artykułach eksponował wizerunek kobiet polskiej, jak i zagranicznej sceny politycznej. Ze względu na wyjątkowe osobowości, ale też bieżące sprawy i wydarzenia, w których uczestniczyły, powtarzalność niektórych nazwisk jest niezaprzeczalna. „Newsweek Polska” w bardzo podobny, a nawet analogiczny sposób, jak robily to „Wprost” i „Polityka”, prezentował sylwetki takich pań, jak: Merkel, Clinton, Palin, Obama, Thatcher czy księżna Diana. Polskimi kobietami pojawiajacymi się we wszystkich trzech pismach były: Kwaśniewska, Kluzik-Rostkowska, Gronkiewicz-Waltz, Ogórek oraz kobiety ofiary katastrofy smoleńskiej.

Kobietami, o których nie pisano w dwóch poprzednich periodykach były między innymi Ewa Balcerowicz oraz Anne Applebaum. W artykułach „Newsweeka” obie panie pojawiły się na tle

47 [Dostęp: 28.09.2015]. Dostępny w World Wide Web: <http://bit.ly/2gx0w61>. 48 J. Chyłkiewicz, Niech żyje mała różnica, „Newsweek Polska” 2006, nr 33, s. 60; A. Graff, Głosujcie na kobiety!, („Kobieta” 20/2010), „Newsweek Polska” 2010, nr 44, s. 18-19. 
swoich mężów, choć - jak zaznaczały - nigdy nie chciały być w cieniu mężczyzn.

Żona Leszka Balcerowicza prezesa Narodowego Banku Polskiego, w jednym $z$ numerów wyznała - Jestem ekonomistka, mam dorobek. Máz ma swoje życie zawodowe. Słowa prezes CASE (Centrum Analiz Społeczno-Ekonomicznych) miały dać do zrozumienia społeczeństwu, że nie ma nic wspólnego $z$ działalnością męża, co jej zarzucano. Opanowana, kontrolująca każde słowo, ale zarazem stanowcza Balcerowicz robi wszystko, by wykazać, że sama, a nie przy pomocy męża (jak się większości ludziom wydaje), jest aktywną, spełniajaca się zawodowo kobieta ${ }^{49}$.

A. Applebaum również pojawiła się na łamach „Newsweeka” w towarzystwie swego męża Radosława Sikorskiego, który wówczas startował w wyborach prezydenckich. Prasa przedstawiła życie prywatne małżeństwa, nie zapominając o ich indywidualnych ścieżkach życiowych. Publicyści $z$ jednej strony ukazywali obraz Applebaum jako niezwykle ciepłej osoby, pochodzacej $z$ dobrego domu, ambitnej, świetnie wykształconej, fantastycznej dziennikarki, z drugiej zaś upatrywali jej żydowskich korzeni, które miały wpłynać niekorzystnie na kandydaturę Sikorskiego. Chociaż każde $z$ małżonków pracuje na własne nazwisko, Applebaum oznajmiła, że włączy się w kampanię wyborczą męża, by go wesprzeć50.

Popularne wśród mediów były nie tylko kobiety stricte związane $z$ polityka, ale także pierwsze damy, a nawet córki znanych polityków. „Newsweek Polska” w jednym $z$ numerów opublikował tekst pt. Córki stanu, w którym przedstawiał role, jakie pełnią dzieci polityków. Wskazując na Martę Kaczyńska, Kasię Tusk, Agatę Buzek oraz Olę Kwaśniewska, autor tekstu stwierdzał, że córki polityków pomagaja budować wizerunek. Maja trafiać do ważnego elektoratu. I tak na przykład Kasia Tusk, traktowana jako celebrytka o nienagannym wyglądzie, doskonale znajacca się na

49 M. Suchodolska, E. Wesołowska, Nie jestem żona przy mężu, „Newsweek Polska” 2006, nr 35, s. 20-22; W. Maziarski, Komisja wzywa, „Newsweek Polska" 2006, nr 35, s. 19.

50 A. Stankiewicz, T. Deptuła, Para excellence, „Newsweek Polska” 2010, nr 11, s. $17-20$. 
modzie, a w dodatku studiująca i pracująca jednocześnie, miała zyskać dla ojca poparcie młodych ludzi. Podobnie traktowano pozostałe dziewczęta, nie zagłębiając się w ich własny dorobek, były one postrzegane przez pryzmat swoich znanych ojców ${ }^{51}$.

Poza wyżej przedstawionymi sylwetkami kobiet na łamach „Newsweeka Polska” pojawiało się jeszcze wiele innych, bardziej bądź mniej, znanych kobiecych nazwisk. Przetaczały się takie osobowości, jak: Henryka Bochniarz, Beata Sawicka, Erika Steinbach, Małgorzata Mańka-Szulik i wiele innych. Jednakże treści przekazów prasowych odnoszących się do tych pań nie wniosły informacji, które pozwoliłyby na znaczace refleksje dotyczące ich wizerunku.

\section{Podsumowanie}

Analizowane artykuły prasowe „Polityki, „Wprost” oraz „Newsweek Polska” zobrazowały wizerunki kobiet, uczestniczących na polskiej, jak i zagranicznej scenie politycznej. Większość prezentowanych kobiet we wszystkich trzech tygodnikach to kobiety odnoszace sukces w szeroko rozumianym życiu publicznym. Niemal wszystkie artykuły przedstawiaja panie zajmujace wysokie stanowiska w państwie. Pełnią funkcje dyplomatyczne, sa parlamentarzystkami, ministrami oraz zajmują wiele innych ważnych stanowisk na krajowej i zagranicznej scenie politycznej. Wszystkie trzy gazety eksponuja kobiety odnoszące spektakularne sukcesy oraz kariery polityczne. Poświęcone im reportaże, felietony oraz przeprowadzane $z$ nimi wywiady podkreślały przede wszystkim przygotowanie merytoryczne oraz wysokie kompetencje kobiet, dzięki którym moga zajmować wysokie stanowiska w państwie. Ponadto nie brakowało też stwierdzeń odnoszących się do cech osobowościowych, wyglądu zewnętrznego, a nawet życia

51 M. Cieślik, A. Stankiewicz, Córki Stanu, „Newsweek Polska” 2011, nr 20, s. 21-23; A. Pawlicka, M. Marczak, Jazda po nazwisku, „Newsweek Polska” 2012, nr 33, s. 14-15. 
prywatnego, które bez watpienia odgrywają ogromna rolę w karierze zawodowej każdego człowieka.

W odniesieniu do analizowanych przekazów prasowych można wnosić, że wraz $z$ upływem lat nie tylko wzrasta liczba kobiet uczestniczących w życiu politycznym, ale także zauważalna jest zmiana jakościowa, przejawiajaca się w osiaganiu przez nie coraz wyższych stanowisk. Ponadto nasuwajacym się wnioskiem jest fakt, iż prasa jako jeden $z$ głównych środków masowego przekazu eksponuje problematykę kobieca w celu zmiany funkcjonujacych, często błędnych schematów i przekonań o miejscu kobiet w rodzinie, w mniejszym stopniu w życiu publicznym.

\section{Bibliografia}

\section{Publicystyka prasowa}

Apelska J., Trzy Gosiewskie w jednym PiS, „Wprost” 2014, nr 5.

Blinkiewicz A., Nowicka K., Prawdziwa Partia Kobiet, „Wprost” 2007, nr 39.

Bojańczyk A., Zyskiwała z wiekiem, „Wprost” 2010, nr 17.

Bratkowska M., Była wielka Dama, „Wprost” 2013, nr 16.

Bratkowska M., Suka, wiedźma, ikona, „Wprost” 2013, nr 16.

Bunda M., Kobieta pracujaca, „Polityka” 2010, nr 28.

Chyłkiewicz J., Niech żyje mała różnica, „Newsweek Polska” 2006, nr 33.

Ciesiołkiewicz K., Dla niej nie istniały problemy, „Wprost” 2010, nr 17.

Cieśla J., Wilk E., Kobieta petnomocna, „Polityka” 2005, nr 47.

Cieśla J., Rybak A., Przypadki pani Hani, „Polityka” 2006, nr 49.

Cieślik M., Stankiewicz A., Córki Stanu, „Newsweek Polska” 2011, nr 20.

Cosić D., Zombie Diana, „Wprost” 2007, nr 32/33.

Deptuła T., Taka zwyczajna Hillary, „Wprost” 2015, nr 17.

Dziedzic M., Przyczajona lewica, „Polityka” 2014, nr 25.

Dzierżanowski M., Zawsze byłam soba, „Wprost” 2010, nr 16.

Dzierżanowski M., Obrywała za szczerość, „Wprost” 2010, nr 17.

Dzierżanowski M., Prymuska, która się uwielbia, „Wprost” 2010, nr 17.

Dzierżanowski M., Matka IV Rzeczpospolitej, „Wprost” 2010, nr 27.

Gielewska A., Kariatyda i jej szparagi, „Wprost” 2012, nr 47. 
Graff A., Głosujcie na kobiety!, „Kobieta” 20/2010 [w:] „Newsweek Polska" 2010, nr 44.

Jarkowiec M., Clintonowie rzadza. Dynastia, „Wprost” 2014, nr 8.

Jarkowiec M., Grzanie Hillary, „Wprost” 2014, nr 8.

Koziński A., Powrót kobiety, „Wprost” 2006, nr 45.

Kozłowska K., Była polska Desiree Rogers, „Wprost” 2010, nr 17.

Krzemiński A., Żelazna dziewczynka, „Polityka” 2004, nr 45.

Krzymowski M., Pani minister na tropie, „Wprost” 2010, nr 44.

Krzymowski M., Żelazna myszka, „Wprost” 2010, nr 17.

Krzymowski M., Całowali po rekach, „Wprost” 2010, nr 17.

Krzymowski M., Operacja Marta, „Wprost” 2010, nr 25.

Lach A., Kluzica, „Newsweek Polska” 2010, nr 48.

Lubowski A., Hilary do pary, „Polityka” 2014, nr 22.

Łakomski G., Życzliwa bo szczęśliwa, „Wprost” 2010, nr 17.

Łazarewicz C., Ozminkowski V., Strażniczka pamięci, „Newsweek Polska” 2012, nr 41.

Maziarski W., Komisja wzywa, „Newsweek Polska” 2006, nr 35.

Mazurczyk A., Winiecki J., Prymusi i pośle ławki, „Polityka” 2010, nr 24.

Milewski P., Świat według Hillary, „Wprost” 2010, nr 29.

Milewski P., Malinowa Hillary, „Newsweek Polska” 2015, nr 12.

Milewski P., Szanse Hillary Clinton. Prezydentka, „Newsweek Polska” 2014, nr 12.

Milewski P., Plusy ujemne Hillary, „Newsweek Polska” 2015, nr 16.

Nagórska M., Miss Barakuda, „Wprost” 2008, nr 37.

Nałęcz T., Dorabianie gęby, „Wprost” 2004, nr 39.

Nowicka K., Matriarchat IV RP, „Wprost” 2007, nr 32/33.

Olczyk E., Czasami jestem za grzeczna, „Wprost” 2015, nr 19.

Ostrowski M., Winiecki J., Niech żyje mała różnica, „Polityka 2009, nr 10.

Paradowska J., Dąbrowska A., Liderzy, debiutanci, maruderzy, „Polityka” 2008, nr 39.

Pawlicka A., Marczak M., Jazda po nazwisku, „Newsweek Polska” 2012, nr 33.

Pawlicka A., Łakomski G., Belferka z Belwederu, „Wprost” 2010, nr 43.

Podgórska J., Po niej już nigdy nie było tak samo, „Polityka” 2004, nr 10.

Podgórska J., Po niej już nigdy nie było tak samo, „Polityka 2004, nr 6.

Podgórska J., Chcemy całego życia!, „Polityka” 2008, nr 48.

Rybak A., Róża Europy, „Polityka” 2004, nr 8.

Rybarczyk M., Największa po Churchillu, „Newsweek Polska” 2013, nr 16. 
Sachno S., Misjonarka Candoleezza Rice, „Wprost” 2008, nr 35.

Sachno S., Sijka A., Pary władzy, „Wprost” 2008, nr 42.

Sadowski G., Fita-Czuchnowska M., Doktryna Condoleezzy, „Wprost” 2006, nr 36.

Safuta M., Twarze komisarzy, „Polityka” 2004, nr 22.

Sowell T., Typki w Białym Domu, „Wprost” 2008, nr 22.

Stankiewicz A., Deptuła T., Para excellence, „Newsweek Polska” 2010, nr 11.

Suchodolska M., Wesołowska E., Nie jestem żona przy mężu, „Newsweek Polska" 2006, nr 35.

Szostkiewicz A., Tańce i łzy, „Polityka” 2013, nr 16.

Tacy byli (dodatek), „Newsweek Polska” 2010, nr 17.

Urbanowicz J., Stalowa magnolia Busha, „Wprost” 2004, nr 22.

Wilk E., Babskie gadanie, „Polityka” 2014, nr 13.

Winnicka E., Jak wychować dziecko w weekend, „Polityka” 2004, nr 6.

Wójcik M., Buchowski M., Władza kobiet, „Wprost” 2009, nr 10.

Wójcik M., Wpływowe kobiety polityki, „Wprost” 2010, nr 11.

Wronowska K., Bestia i piękna, „Wprost” 2010, nr 39.

Zalewski T., Dynastia, „Polityka” 2015, nr 16.

Zalewski T., Jastrzą $w$ szpilkach, „Polityka” 2008, nr 49.

Żakowski J., Kluziki na kredyt, „Polityka” 2010, nr 49.

\section{Zasoby internetowe}

[Dostęp: 28.09.2015]. Dostępny w World Wide Web: <http://bit.ly/ 2gx0w61>.

[Dostęp: 2.09.2015]. Dostępny w World Wide Web: <http://bit.ly/ $2 \mathrm{fQ} 27 \mathrm{Db}>$.

\section{Opracowania}

Dajnowicz M., Wizerunek kobiet polityki. Polska na tle państw zachodnich (na podstawie analizy treści wybranych tygodników), „Studia Podlaskie" 2014, t. 22.

Dobek-Ostrowska B., Polski system medialny na rozdrożu: media $w$ polityce, polityka $w$ mediach, Wrocław: Wydawnictwo Uniwersytetu Wrocławskiego, 2011, ISBN 978-83-229-3183-7.

Hofman I., Wzór redaktora - model redakcji: „Tygodnik Powszechny”, „Polityka”, „Twórczośc”" [w:] Prasa dawna i współczesna, cz. III, red. B. Kosmanowa, Poznań 2002, ISBN 8387704466. 